\title{
Multiliteracies in Teaching Materials of Fiction Prose Study based Ador-Meverlee
}

\author{
Elyusra $^{1}$, Dian Susyla ${ }^{1}$, Dian Eka Chandra ${ }^{2}$, Syanurdin $^{3}$ \\ ${ }^{1}$ Faculty of Teachers Training and Education, Muhammadiyah University Bengkulu, \\ Indonesia \\ ${ }^{2}$ Faculty of Teachers Training and Education, University of Bengkulu, Indonesia \\ ${ }^{3}$ Faculty of Teachers Training and Education, University of Prof. Dr. Hazairin, Indonesia \\ E-mail: elyusra@umb.ac.id
}

\begin{abstract}
This article aims to report on the multiliteracies that can be mastered by students taking part in the subject of Fiction Prose Study using AdorMeverlee based teaching materials (advance organizer-meaningful verbal learning-elaboration) at the Faculty of Teachers Training and Education, Muhammadiyah University of Bengkulu. The research design that is used in compiling teaching materials is Research and Development with three main steps. The stages of the activities carried out are: theoretical studies and research, planning and production activities. The results of the research stated that the structure of the Ador-Meverlee based teaching materials for Fiction Prose Study consisted of: instructional material structure, language structure, understanding structure, display structure, text structure, and stimulant structure. The preparation of the structures of the Ador-Meverlee based teaching materials for Fiction Prose Study fulfills multimodal learning, fulfills the principle of multiliteracies learning: interpretation, collaboration, convention, cultural knowledge, problem solving, reflection, and language use, also fulfilling the stages of multiliteracies learning. In addition, the Ador-Meverlee based teaching materials for Fiction Prose Study can facilitate students in multiliteracies efforts in the form of: spatial-visual, linguistic- verbal, kinesthetic, interpersonal. moral, life skills, culture or literature, and religious.
\end{abstract}

Keywords: Advance Organizer; Teaching Materials of Fiction Prose Study; Verbal Learning; Multimodal, Multiliteracies.

\section{INTRODUCTION}

Basically, literacy in Indonesia has been encouraged since the colonial era, both by natives and colonists. Already known general, that Indonesia has literacy activists who are reliable and qualified, even recognized by the world. Figures like R.A. Kartini, Dewi Sartika, Ki Hajar Dewantara, Rohana Kudus, and Kyai Rifa'i quite represent this thinking[1]. Currently in 
Indonesia the National Literacy Movement is being promoted which must be supported by all citizens.

In literacy education institutions are important issues. This is due to the need for educational institutions to prepare human resources capable of playing a role in the community. To meet these needs various efforts have been carried out, both in the form of the procurement of new programs, as well as the integration of existing programs, such as the changes in the curriculum that were implemented. The implementation of literacy programs is the responsibility of many parties. In college, this program is the responsibility of the leadership at various levels, various related units, such as instructional quality assurance units, libraries, and laboratories. Lecturers as lecturers are parties who have an important responsibility and role for the success of literacy programs, especially in the implementation of the courses they provide.

Literacy is not a static thing that runs linearly. Literacy always adjusts to a context, such as the circumstances of the time and the setting of the place. Changes in the way of communication that occurs in the global era today requires the transition of conventional literacy concept (reading-writing) from texts as a symbol / printed texts to the concept of broad meaningful texts. Texts are not only the writing in printed form, but including digital writing, images, films, videos, and even natural phenomena. Thus, inevitably, the multimodal concept or the amount of entitled materials must be integrated in the teaching-learning process. In fact, multimodal in the learning process has become a necessity. It is motivated by the finding that students are human beings who in essence have various kinds of intelligence that must be considered in determining learning policies, who potentials must be developed, even must be served. Multimodal is the view that various materials (capitals) can be utilized in learning[2]. This will be able to achieve the multiliteration in students.

Multiliteracies is a competency that must be possessed by students to be able to solve problems that they are facing in their lives. The multiliteracies implementation conducted by Graham, Berson, and Fink is oriented to the multimodal aspects of literacy[3]. Gardner states that there are eight intelligences in each student. Bobbi dePorter et. al. created an interesting acronym for Gardner's theory with the name SLIM-n-BIL[4]. The eight intelligences in the acronym are: Spatial-Visual (intelligent in describing or imagining); Verbal-Linguistics (intelligent in language); Interpersonal (intelligent in interacting with a community); MusicalRhythmic (intelligent in singing and playing musical instruments); Naturalist (intelligent in dealing with nature and its contents); Bodily-Kinesthetic (intelligent in the body); Intrapersonal (intelligent in understanding one-self); Logical-mathematical (intelligent in counting). Boeriswati stated that multiliteracies is closely related to reading and writing with complex aspects[5]. From another perspective, the variety of literacy is also in the form of moral literacy.

Furthermore, Boeriswati emphasized that $21^{\text {st }}$ century literacy education is intended to train students to be skilled in processing and communicating information[5]. Therefore, literacy requires a range of cognitive abilities, written and oral language knowledge, knowledge of genres, and cultural knowledge. There are seven principles of literacy education that must be implemented in learning expressed by Kern with following keywords: interpretation, collaboration, convention, cultural knowledge, problem solving, reflection and self reflection, and also language use[5].

As the actor that interacts with students a lot, the lecturer of the Fiction Prose Study can carry out their role through the provision of teaching materials that are able to achieve the various multiliteracies abilities mentioned above. Teaching materials are defined as everything 
that can help the implementation of teaching-learning processes that contain messages, and arranged systematically[6]-[8]. Some principles that must be considered in developing teaching materials are: goal-oriented, relevance, efficiency and effectiveness, flexibility, continuity, balance, integration, quality, and adequacy (adequacy)[7]. Tomlinson says that teaching materials should have an impact, with four indicators, namely: novelty, variety, attractive, presentation, and appealing content[6]. Related to the preparation of printed teaching materials, Steffen Peter Ballstaedt stated that the developer must pay attention to several things, namely: arrangement of appearance, easy language, testing comprehension, stimulants, ease of reading, and instructional material[9].

The available teaching materials have not been able to guide the students to master Fiction Prose Study with good competencies, have not maximally fulfilled multimodal learning, so that it is difficult to actualize multiliteracies that students currently need. Therefore, it is necessary to prepare Fiction Prose Study teaching materials specifically to meet the needs. The design of teaching materials needs to be compiled by applying a model of meaningful verbal learning, namely meaningfulness in learning through language. "Meaning" is defined as a combination of verbal information, concepts, rules and principles, which are reviewed together. According to Ausubel, in order to make the learning process produces something meaningful is not entirely the responsibility of the students[10]. The integration of new knowledge and understanding into the cognitive framework that students already have can be helped by the teacher through teaching material models.

Starting the presentation of teaching materials with an advance organizer can be a motivating strategy and is believed to strengthen the cognitive structure of students. Ausubel stated an advance organizer model was designed to strengthen the cognitive structure of students of certain lessons and how to manage, clarify, and maintain that knowledge well[11].

There are three main stages in the advance organizer model: presentation of advanced organizer, presentation of assignments or learning material, and strengthen the cognitive processing. The peculiarity of this model lies in the first stage, the advance organizer's presentation, in the form of clarifying learning objectives, presenting the material arrangements, identifying conclusive characteristics, giving examples, and presenting context. In the first stage, repetition and encouragement for the awareness of students' knowledge and experience are also given. It is stated that this model requires teaching materials to be compiled with a wealth of data and good preparation[11].

In line with the model above, elaboration theory was put forward by Reigeluth and Stein with seven main components, namely: 1) elaborative sequence, 2) the sequence of learning prerequisites, 3) summary, is a review to maintain retention; 4) siteers (synterizer 5) analogy, 6) cognitive strategy activator; 7) learning control[12]. Elaboration theory runs with seven principles: (1) the presentation of the content framework presented in the first phase of teaching, (2) the part covered in the content framework is gradually elaborated, (3) the most important part is presented first, (4) the depth and vastness of each elaboration is done optimally, (5) penistensis is given after each elaboration, (6) the synthesizing type is adjusted to the type of subject matter, and (7) a summary is given after each syntheses[13]. Merrill stated that additional forms of elaboration that can be used include: elaboration of preconditions, contextual elaboration, mnemonic elaboration, matematic elaboration, representave elaboration or alternative representation, and feedback or knowledge regarding the results achieved[14]. The use of this elaboration is believed to be able to overcome the students difficulties of learning 
the materials in the form of concepts, principles, and procedures with unfamiliar diction/lexical and complex, abstract, and in big amount.

\section{METHODS}

The research method used is the Research and Development method. According to Borg \& Gall "educational research and development (R \& D) is a process used to develop and validate educational products"[15]. Teaching materials are developed to determine user needs with detailed specifications[16]. At the completion stage, products are field tested and revised until a certain level of initial effectiveness is achieved[16], [17]. The product in the context of educational research and development is in the form of developing a model of Fiction Prose Study teaching material, which is prepared according to the needs of students and lecturers at the Faculty of Teachers Training and Education, Muhammadiyah University of Bengkulu, followed by field tests and revisions to obtain effective products.

The development model is combined model of Jolly Bolitho and Tomlison[18]. With this design, research is carried out with three main steps, namely: theoretical studies and research, planning and production, field testing and revision. To get the initial product, a literature study was carried out, also identification of needs, reviewing available teaching materials, and formulating the principles of teaching material models. In the second stage, activities were carried out to compile syllabus and produce teaching materials. In the third stage an initial field test was carried out to get input from users.

Data was collected by questionnaires and interviews. Instruments are developed with evaluation criteria for teaching materials. The validity of the instrument in the form of content validity is obtained through the preparation of the instrument grid. The research subjects were 100 students and four lecturers. Data were analyzed descriptively and with content analysis techniques.

\section{RESULT AND DISCUSSIONS}

The product of development in this research is Ador-Meverlee based Fiction Study Prose textbook. The structure of the Fiction Prose Study Teaching Material Based on Ador-Maverlee consists of: 1) instructional material structure, 2) language structure, 3) understanding structure, 4) display structure, 5) text structure, and 6) stimulant structure. Explained below are the multiliteracies in the structure of the teaching material products.

\subsection{Multiliteracies in Instructional Material Structure of the Ador-Maverlee-based Teaching Materials for Fiction Prose Study}

The instructional material structure is the structure of learning materials with consideration of material selection and preparation. The stipulated material is prepared with the following ten criterias in mind: 1) Teaching materials must be oriented towards achieving the Learning Outcomes wich was set by the study program association and the profile of graduates of the educational unit characteristics. 2) The material is adjusted to the student's background on aspects of the level of knowledge, the level of development of psychology, and aspects of the socio-cultural setting. 3) Sources of teaching materials are varied and it is strongly recommended to use scientific journals as sources. 4) Elements of character, local wisdom, and non gender-bias are integrated into teaching materials. 5) Teaching materials are in the form of 
knowledge of Fiction Prose works and Fiction Prose Study, 6) Teaching materials are in the form of reading and writing skills in Fiction Prose. 7) Teaching materials can guide students to have a positive attitude towards Fiction Prose Study. 8) Teaching materials can build learning skills, 9) Materials are selective. 10) Teaching materials include the types of concept/definition materials, principles, procedures, and values.

In the structure of the material above, the multiliteracies components are very diverse. Students are equipped with a fundamental component of multiliteracies in the form of reading and writing skills which are stated explicitly. Other literacy components that students will have are: linguistics-verbal, information literacy. The choice of literature texts can be done with the aim of equipping students with moral literacy, life skills literacy, cultural literacy or literature literacy, and religious literacy.

The results of Fiction Prose Study communicated verbally by students in class can achieve multiliteracies in the form of linguistic-verbal, gestural, and interpersonal competencies. This learning activity also fulfills all the principles of literacy learning, namely the principles of interpretation, collaboration, convention, cultural knowledge, problem solving, reflection, and language use.

\subsection{Multiliteracies in Language Structure of the Ador-Maverlee-based Teaching Materials for Fiction Prose Study}

The language structure of the Ador-Maverlee-based teaching materials is oriented towards a model of meaningful verbal learning. Through exposure to materials, students are helped to integrate their new knowledge and understanding into the cognitive framework they already have. In addition, material exposure was also encouraged by students to be aware with the importance of knowledge and experience. Other characteristics, the language used is formal varieties, logical and communicative sentences, and paragraph structures that is coherence with good correlation between sentences.

The language structure of teaching materials is able to equip students with verbal-linguistic abilities. The use of diverse languages in materials fulfills the principles of multimodal learning that effectively meet student learning styles. Ausubel states that learning through exposure of using good language can achieve meaningful learning[10].

\subsection{Multiliteracies in the Structure of Understanding of the Ador-Maverlee-based Teaching Materials for Fiction Prose Study}

The understanding structure of the Fiction Prose Study teaching material that is based on Ador-Maverlee is built by taking into account nine criterias. The criterias are: 1) identifying conclusive characteristics, 2) giving examples, 3) presenting context, 4) repeating, 5) clarifying material processing, 6) strengthening cognitive processing, 7) using analogies, 8) presenting syntheses or links interface.

The application of the eight criteria mentioned above in teaching materials thoroughly fulfills the multimodal learning model which is also capable of achieving multiliteracies learning. The understanding structure of teaching materials above can help students develop optimally. 


\subsection{Multiliteracies in Text Structure / Readability of the Ador-Maverlee-based Teaching Materials for Fiction Prose Study}

Text Structure/ Readability of the Fiction Prose Study teaching material that is based on Ador-Maverlee is prepared by paying attention to its usefulness in assisting the implementation of the teaching and learning process and assisting the implementation of learning administration. In addition, teaching materials can activate the cognitive strategies of students, both because of their use or by telling students to use them and teaching materials are easy to understand. The text structure of this teaching material fulfills the characteristics of multiliteracies in line with the context.

\subsection{Multiliteracies in the Stimulant Structure of the Ador-Maverlee-based Teaching Materials for Fiction Prose Study}

The stimulant structure of the Fiction Prose Study teaching material that is based on AdorMaverlee was sought by providing learning control in terms of material choices, speed, and learning style. Teaching materials are arranged with sufficient depth and vastness of materials. Teaching materials are arranged with varied elaborations. Teaching materials are written in the form and size of letters, topography, and good supporting images. The stimulant structure of teaching materials above fulfills multimodal learning and is multiliterative learning. The principle of literature learning in terms of the use of language and the provision of cultural knowledge is very fulfilled.

\subsection{Multiliteracies in the Structure of Display of the Ador-Maverlee-based Teaching Materials for Fiction Prose Study}

The various structures for the preparation of the Fiction Prose Study teaching material that is based on Ador-Maverlee are presented in a display structure that includes seventeen components. The display structure of this teaching material is in the form of a book. Textbooks consist of sections: title page, introduction, table of contents, learning objectives, learning benefits, material framework, learning instructions, learning prerequisites, learning material, work assignments and steps, maintaining attention, assessment, summary, and bibliography. The various components above are arranged systematically.

Teaching materials in the form of a book have a complex display structure. This can provide a broad opportunity to apply multimodal learning, fulfill various principles of multiliteracies learning, and follow the stages of multilitaracies learning. The introductory part of this teaching material is very rich, so that it fully meets the stages of visualizing multiliteracies education in the $21^{\text {st }}$ century suggested by Boeriswati[5]. The visualizing stage in the structure of teaching materials can maximally help students to have a clear picture of goals, ways of achieving, and measuring learning outcomes. The task of summarizing teaching materials in the form of mind map can help students to have spatial-visual literacy and achieve maximum retention levels. In general, the potential display structure embodies multiliteracies for students.

\section{CONCLUSION}

Based on the results of the study, the following points can be concluded. First, the structure of the Ador-Maverlee-based teaching materials for Fiction Prose Study consists of six 
structures, namely: structure of instructional material, language structure, understanding structure, display structure, text structure, and stimulant structure. Second, the structuring of Ador-Maverlee-based teaching materials for Fiction Prose Study has fulfilled multimodal learning. Third, the Ador-Maverlee-based teaching materials for Fiction Prose Study fulfills the principles of multiliteracies learning: interpretation, collaboration, convention, cultural knowledge, problem solving, reflection, and language use. The four structures of the AdorMaverlee-based teaching materials for Fiction Prose Study meet the stages of multiliteracies learning. Fifth, Ador-Maverlee based Fiction Prose Study teaching materials can facilitate students in multiliteracies efforts in the form of: spatial-visual, linguistic-verbal, bodilykinesthetic, interpersonal, moral, life skill, culture or literature, religious.

\section{REFERENCES}

[1] R. Nurfaidah, "Konsep Literasi dalam Telaah SIBI 2016: Sebuah Kajian Interteks Tahap Awal," SEMANTIK, vol. 6, no. 1, pp. 37-45, 2017.

[2] D. D. Hassett and J. S. Curwood, "Theories and Practices of Multimodal Education: The Instructional Dynamics of Picture Books and Primary Classrooms," Read. Theacher, vol. 63, no. 4, pp. 270-282, 2009.

[3] E. S. Sari, S. Maman, and L. Beniati, "Model Multiliterasi dalam Perkuliahan Pendidikan Bahasa dan Sastra Indonesia," LITERA, vol. 12, no. 2, pp. 246-255, 2013.

[4] B. DePorter and et al, Quantum Teaching: Mempraktekan Quantum Learning di Ruangruang Kelas. Bandung: Mizan Media Utama, 1999.

[5] E. Boeriswati, "Pembelajaran Literasi Abad 21," 2016.

[6] B. Tomlinson, English Language Learning. London: Continuum, 2008.

[7] Ismawati, Pengajaran Sastra. Yogyakarta: Penerbit Ombak, 2013.

[8] Penen and Purwanto, "Penulisan Bahan Ajar," in Mengajar di Perguruan Tinggi, Jakarta: Depdikbud, 1997.

[9] Depdikbud, Perangkat Pembelajaran KTSP SMA. Jakarta: Depdikbud, 2008.

[10] W. S. Winkel, Psikologi Pengajaran. Yogyakarta: Media Abadi, 2007.

[11] B. Joyce, M. Weil, and C. Emily, Models of Teaching. Yogyakarta: Pustaka Pelajar, 2011.

[12] C. M. Reigeluth and F. S. Stein, "The Elaboration Theory of Instructional," in Instructional-Design Theories and Models: An Overview of Their Current Status, C. M. Reigeluth, Ed. New Jersey: Lawrence Erlbaum Associates, 1983.

[13] I. N. S. Degeng, Ilmu Pengajaran Taksonomi Variable. Jakarta: Depdikbud, 1989.

[14] M. D. Merrill, "Component Display Theory," in Instructional- Design Theories and Models: An Overview of Their Current Status, C. M. Reigeluth, Ed. New Jersey: Lawrence Erlbaum Associates, 1983.

[15] W. R. Borg and M. D. Gall, Educational Research: An Introduction. New York: Longmen, 1989. 
[16] Emzir, Metodologi Penelitian Pendidikan: Kuantitatif \& Kualitatif. Jakarta: Raja Grasindo Persada, 2010.

[17] Sugiyono, Metode Penelitian Pendidikan. Bandung: Alfabeta, 2008.

[18] B. Tomlinson, Materials Development in Language Teaching. Cambridge: CUP, 1998. 